\title{
Critical Research in Sport, Health and Physical Education
}

How to Make a Difference

Edited by Richard Pringle, Håkan Larsson and Göran Gerdin

First published 2019

ISBN 13: 978-1-138-57167-9 (hbk)

ISBN 13: 978-0-203-70259-8 (ebk)

Chapter 5

Critical research on Black sporting experiences in the United States: Athletic activism and the appeal for social justice

Billy Hawkins

CC BY-NC-ND 4.0

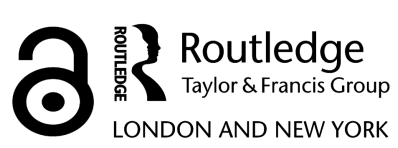




\title{
Critical research on Black sporting experiences in the United States: Athletic activism and the appeal for social justice
}

\author{
Billy Hawkins
}

\section{Introduction}

It is impossible to discuss the intersection of race and sport without providing an overview of the current context whereby the discussion of these topics is situated in the United States. In providing a context for this chapter, I am reminded of the song, "The thrill is gone." This song was made famous in 1970 and garnered the late great B.B. King a Grammy Award for Best Male R\&B Vocal Performance. The lyrics of this song expresses the woes of being mistreated while caught under the spell of love. Prior to the election of President $\# 45^{1}$, many Blacks ${ }^{2}$ I have communicated with entertained a type of thrill, a mild euphoric sensation that stemmed from the symbolic empowerment the former President Barack Obama provided during his two-term tenure in the White House. It was a type of love affair with the prospect of change and in a hope that the United States might be capable of living up to the potential stated in its Declaration of Independence, where it declares that:

We hold these truths to be self-evident, that all men are created equal, that they are endowed by their Creator with certain unalienable Rights, that among these are Life, Liberty and the Pursuit of Happiness.

Though the creators of this document did not factor in women or people of color during its inception we have had to make it work for us, even though the spirit of its content should guarantee provisions for us today. This chapter will seek to provide an overview of the literature on race and sport, explore critical insight about existing knowledge on race and sport, and finally highlight research that is seeking to produce emancipatory structures for racial justice. The limitation of this chapter is that it will favor the Black athletic experience predominantly, with cursory attention to other emerging racial populations; for example, Latin Americans in baseball or Pacific Islanders in American collegiate and professional football.

In the United States, one can conclude that since the creation of this sacred document to the election of President Obama there have been changes in race 
relations and racial equality, with some efforts toward racial equity in this country. Therefore, upon President Obama's initial election, we were caught under a spell that the prophet of hope preached during his presidential campaign; our expectation for change was high, yet at the close of a chapter in U.S. history in 2016, during the sunset of this nations' first Black President's tenure in the White House, myself and many Blacks I know were left wanting. The celebratory outlook we had during his first election lingered throughout his second term, until the increased racial tension and violence against Blacks caused many to question whether having a 'Black face in high place', according to the late Professor Manning Marable (1998), could make a difference. At a time when this country could have embraced the hope of racial inclusion and progress towards a post-racial society, we have witnessed a rise in racial crimes and lenient or no punishment to the perpetrators of these violent crimes; indeed, several of the perpetrators were those who were charged with the duty to protect and serve.

Furthermore, the thrill is gone because in this age of social media and the preeminence of the visual culture, on display in the highest political office in this nation is a clear definition of "unobstructed" white male privilege. We are consistently receiving images and verbal text from this administration that blatantly defines and clearly demonstrates an unobstructed privilege that white males have enjoyed since they assumed it was their duty to control the world through colonization and imperialism. What has emerged from this revitalization of unobstructed privilege is the fortification of institutional racism and radicalization of individuals who act violently in expressing their flawed racist beliefs.

The world is watching as the president of the most powerful nation in the world demonstrates, and has demonstrated prior to taking office, what it means to have unobstructed white male privilege. It is that ability to say and do whatever you want with little to no repercussions, no moral checks and balances, and no intellectual filters to regulate ones' actions. It is also the ability to censure, fire, discredit, and/or degrade anyone who doesn't agree with you without consequences. It is like having access and opportunity to whatever you want regardless of who owns it or whose feelings you might hurt in taking what you want, saying what you want, and simply doing whatever you want.

To further examine the social context where race matters and racism prevails, we have to critically deconstruct how President \#45 is exhibiting actions towards people of color that clearly align themselves with the actions of white supremacists. For example, he and his administration established a travel ban on predominantly Muslim countries, which are, typically people of color; his administration seeks to build a wall to keep Hispanics out (also people of color); his administration initially rescinded DACA (Deferred Action for Childhood Arrivals) policy and unveiled a restrictive reform policy known as the SUCCEED Act; he and his administration treated Puerto Ricans and Puerto Rico, like America's sidepiece, not warranting the full attention or resources to meet their dire needs and jokingly tossing rolls of toilet paper amidst a crowd of Puerto Ricans while 
blaming them for his administration's budget woes; another example is where he referred to members of the Klu Klux Klan (KKK), one of the most notorious terrorist organizations in American history especially in regards to acts of terrorism against Blacks, as "good people" but referred to Black National Football League (NFL) players who peacefully protested racial injustices in this country by taking a knee during the singing of the national anthem as, "Sons of Bitches"; finally, in a discussion on immigration, he has referred to African immigrants as individuals seeking to migrate from "shithole" nations. The list of racially charged and sexist acts goes on by a leader who arrogantly and boastfully demonstrates unobstructed white male privilege, while simultaneously radicalizing white supremacy.

This unobstructed privilege enables supporters of President \#45's tweet about the NFL players to project their slave-master's ideology on people of color, in general, and Blacks, specifically. For example, these supporters have asserted that professional Black male athletes should be grateful for the amount of money they are making, thus, they should just shut up and play ball. These supporters also proclaim that the game should not be politicized. They forget that the entry of the national anthem or the presence of the American flag automatically politicizes these sporting events and venues, because how can you separate the political ideology of a nation from the national symbols that distinguishes it from other nations? These sporting venues have been and continue to be ideological outposts for political propaganda about nationalism. But these supporters are disgruntled because a few NFL players protest. Thus, once again, we have whites seeking to control the Black body, establishing parameters within which it can exist, and determining how the Blacks are supposed to behave.

This behavior, within the broader socio-historical context, continues to entrench a racial divide in a country that has never adequately addressed its race problem. The United States has never truly atoned or provided sufficient reparations for the millions of Native Americans who suffered genocide or for the millions of lives that were displaced because of the Atlantic slave kidnapping and slavery. The United States has never sought to provide Native Americans or Blacks with the equal access to opportunities that the majority of whites assumed from birth. There are a few universities that are acknowledging their connections to and benefits from slavery with token concessions. ${ }^{3}$ Yet the racial wounds are deep and have been festering for hundreds of years. The United States has tolerated this illness, ignored it symptoms, while only superficial treatment has been applied with the hope that it will get better. Despite, making some symbolic progress when this nation elected President Barack Obama to two terms, the progress to a post-racist society has been held captive. The momentary destabilization of hopelessness fostered by the prophet of hope has been undermined and dismantled by President \#45.

Again, this is the social context in which the intercentricity of race and racism are currently being played out. There is historical precedence in the United States for the current racial climate. Protests and social movements have fostered the ebbs and flows of race relations and racial justices and not the moral 
development of this nation. Sporting experiences have mirrored this pattern as well. The disease of white supremacy and unobstructed white male privilege continues to undergird the social institutions of this nation and sport is not inoculated against the associated psychosocial damage. It has been and continues to be a contested terrain in which racial ideologies are reflected, reinforced, and at times resisted. Thus, black male and female athletes, specifically, have exhibited both tragedy and triumphs. Sport has provided opportunities on and off the field, while simultaneously reinforcing notions of scientific racism where Blacks are still perceived to be athletically superior but intellectually inferior.

\section{Overview of race and sport literature}

Research on Black sporting experiences have mainly addressed issues of representation and discrimination, or it has focused on ideological issues about race and racialized identities and performance. Regarding issues of representation and discrimination, positional segregation or stacking based on race in collegiate and professional sports has been well-documented (e.g., Davis, 1990; Berghorn, Yetman, and Hanna, 1988; Koch and Vander Hill, 1988; Leonard, 1987; McPherson, 1976; Johnson, and Marple, 1973; Loy and McElvogue, 1970). This research is based mainly on Blalock's work on occupational discrimination and his theoretical assumptions about minority group relations (Blalock, 1961 and 1967). It highlights how race has determined the positions Black athletes could or could not occupy. For example, the racialization of these positions classifies them as "thinking" positions, where White athletes are expected to play, and "non-thinking" positions, where Black athletes are expected to play. To further expound, "thinking" positions (e.g., quarterback, pitcher, and center) are the leadership position in which a disproportionate number of White athletes occupied during the 1960s-1990s when the majority of the data for this research was collected. Conversely, Blacks occupied the majority of "non-thinking" positions (e.g., running backs, outfielders, forwards). These categories are used to describe positions mainly in the sports of football, basketball, and baseball, also because the majority of the research has examined these three sports.

The research on positional segregation has expanded beyond binary racial categories of black and white and beyond the traditional sports of basketball, baseball, and football to include, for example, the stacking of Aboriginal hockey players in Canada in the role of enforcers (Valentine, 2012); racial segregation of Black soccer players in the non-central forward position, based on stereotypical beliefs about racial abilities (Maguire, 1988; Melnick, 1988); or Aborigines in Australian Rugby League racially segregated in non-central positions (Hallinan, 1991).

Of importance is that the racialization of positions is not only based on perceived assumptions about racialized performance, but more so on racial ideologies that are rooted in the beliefs from scientific racism which claim to prove that Blacks are genetically physically superior, and Whites are intellectually superior. What is also inherent in the practice of stacking, in regard to Black athletes, is 
the intercentrality of race and pervasiveness of racism. Even with the increased representation of Black athletes at the quarterback (QB) position in football, the intercentricity of race and racism prevails because expectations for Blacks in this position are to be mobile (i.e., exploit their physicality). Therefore, the Black QB is a multiple threat to the defense, unlike the traditional drop-back or pocket passing White QB. Because of the Black QB's perceived physical abilities, he becomes an additional running back in conjunction with his passing abilities. Once again, reinforcing racialized assumptions about physicality and athleticism and exploiting these assumptions for a competitive advantage.

\section{Racial and athletic identity and the Black athlete}

African American racial identity and sport is another popular area of research that has gained traction in examining how the theory of racial identity development can assist in explaining the over-representation of African American in certain sports and the under-representation in others (see, e.g., Harrison, Harrison, and Moore, 2002). Also, how racial and athletic identities can impact sporting and lived experiences for Black athletes in the collegiate context (see, e.g., Steinfeldt, Reed, and Steinfeldt, 2009; Bimper and Harrison, 2011). Researchers in this area consider the relationship between racial identity and athletic identity and are seeking to explain how the socialization processes of race and sport may impact academic performance and outcomes.

Other works regarding issues of representation and Black sporting experiences include the works of Dr. Richard Lapchick and The Institute for Diversity and Ethics in Sport's annual publication of the Racial and Gender Report Card. This work has been instrumental in assessing the representation of people of color in leadership positions in professional and collegiate sports. This Institute also catalogues the National Collegiate Athletic Association (NCAA) graduation rates of major NCAA sporting events (e.g., Division I men's and women's basketball tournament, Bowl-Bound college football teams, and Super Regional Men's baseball teams), as well as the racial and gender representation of the creative directors who are responsible for which advertisement spots are broadcasted during the Super Bowl (TIDE, 2018). And finally, the works of Dr. Shaun Harper and the Center for the Study of Race and Equity in Education. One of this Center's report entitled, Black Male Student Athletes and Racial Inequities in NCAA Division I College Sports: 2016 Edition, exposed the racial inequalities in the Power 5 conferences (Harper, 2016).

Both of these efforts have policy implications in terms of increasing diversity and inclusion at the professional and collegiate levels as well as promoting programmatic policies needed to increase the degree attainment of athletes who are in highly commercial time-demanding revenue generating sports. This research on representation also exposes the pervasiveness of race and racism in sport and the discriminatory practices inherent in sporting practices in the United States. 


\section{Black women sporting experiences}

A growing body of literature has developed on the study of Black women's sporting experiences. This research has emerged as a necessary addition to the literature on race and sport in the U.S. Scholars have engaged this topic by examining the historical and current sporting experiences of Black women (see, e.g., Cahn, 1994; Leonard, 2014; McDowell, and Carter-Francique, 2016; Sloan-Green, Oglesby, Alexander, and Franke, 1981; Smith, 1992, 2000). The research on Black women's collegiate experiences have grown exponentially (e.g., Bruening, Armstrong, and Pastore, 2005; Carter, 2008; Bernhard, 2014; Carter-Francique and Richardson, 2015; Cooper, Cooper, and Baker, 2016). Professional and collegiate sport remain sites of hegemonic masculinity, thus, these scholars are examining how the oppressive structures and culture are contributing to the lack of Black women in administrative positions and their experiences as athletes.

These scholars and many others who are contributing to the examination of Black women sporting experiences are exposing the varying jeopardies Black women encounter as being Black, women, athletes, sexuality, and from a certain socioeconomic group. These scholars are also illustrating how the intersectionality of these jeopardies have impacted the sporting experiences of Black women in unique ways often causing them to triumph in the face of tragedy and be trendsetters in sports previously reserved for upper-class white women; especially in the case of being isolated and denied access to all-white women's division during the early years of women athletic competition in the United States. For the first time in U.S. Open history in 2017, three Black women advanced to the quarterfinals created a counter narrative to the dominant narrative about Black women in country club sports. Similarly, the scholars who are producing research on Black women sporting experiences are challenging stereotypical notions and the dominant narrative about Black women athleticism and femininity.

\section{Critical insight on race and sport}

The work of Dr. Harry Edwards has made an indelible imprint in the literature on race and sport. As one of the forerunners and trendsetters for studying race and sport, his work continues to provide critical insight on the subjects of race and sport. His 2016 NASSS keynote address provided critical historical overview of what he calls "the trajectory of the development at the interface of sport, race, and society in America" (Edwards, 2016). He captures the Black sporting experiences using four waves: The first wave involved athletes like Jack Johnson, Major Taylor, Paul Robeson, Jesse Owens, Joe Louis, and others who struggled for legitimacy in expressing their athletic talents at both the national and international levels; the second wave represented the Black athletes who were cautioned to be politically silent on issues of race and discrimination, but who sought to work within the systems of desegregation until they could gain access to white only professional sporting leagues and universities; the third wave produced a politically active and 
racially conscious Black athlete, such as, Bill Russell, Jim Brown, Muhammad Ali, Curt Flood, John Carlos, Tommie Smith, and others who struggled for dignity and respect, but spoke out and demonstrated publicly against racial injustices; and finally the fourth wave involves athletes in pursuit of power, and they are demonstrating it in the form of athletic activism. For example, athletes like Colin Kaepernick are leveraging their publicity and status as professional athletes to make political statements against social injustices (Edwards, 2016). What is critically insightful about Edwards' lecture is the historical role several Black athletes have played in using their status to address broader social injustices.

It has been and continues to be a reoccurring theme with Black sporting practices where Black athletes have had to convert their publicity and status as professional and collegiate athletes into political power to voice their discontent with racial injustices nationally and internationally. Oftentimes it is because the lived experiences of Black athletes are not compartmentalized from the lived experiences of Blacks, in general; that is, the economic gains many Black professional athletes have received have not quarantined them from the racial injustices members of the larger Black population incur. Thus, the athletes who have chosen the path of activism have not opted for political compartmentalization for the sake of maintaining their market value for commercial gains. Future critical inquiry will hopefully provide a counter-narrative to assure that the activist efforts of these athletes are not converted into meaning something else or co-opted and transformed into meaning something less.

Another seminal work that is providing critical insight on the intersections of race and sport is Dr. Ben Carrington's work, Race, Sport, and Politics. He posits that sport contributes to the "making and remaking of western ideas about racial difference" (p. 2). He further asserts that:

throughout the twentieth century and into the present there has been a continuous struggle over the meaning of 'the black athlete'. It has been contested from within and without. (Carrington, 2010, p. 2)

Thus, what once was "developed out of and from a white masculinist colonial fear of loss and impotence, revealing the commingling of sex, class, race, and power," (Carrington, 2010, p. 3) has evolved to satisfy the needs of the power elite through ultra-commercialized collegiate and professional sports and through the process of once again commodifying the black body.

The evolution in meaning of the Black athlete forever binds him/her to the conventions that defines him/her, thus restricting self-expression and/or activism until it is co-opted into the capitalist machinery and converted into profits. For example, according to Heitner (2016), the selling of Colin Kaepernick's jersey rose from the 20th best seller among San Francisco 49ers, before he protested the national anthem, to becoming the number one selling jersey among all NFL players, after he began protesting the national anthem. The Black body, once again, remains useful as commodity on and off the field, where his/her athletic talent 
benefit capitalist elite because they not only control the product 'Black body' producing on the field but also they control the revenue that the Black body's likeness and image can generate.

The critical insight these works provide illustrate that there have been evolutionary strides for Blacks in sport since the days of Jack Johnson, which Carrington (2010) suggests was the making of the Black athlete, however, the advancements Blacks have made in sports has been and continues to be tempered by the intercentricity of race and racism. Race and racism continues as a shadow to the accomplishments of Black athletes. Whether it is couched within comments about the hyper-athleticism of Serena Williams, the "kemptness" of Gabby Douglas' hair, or the continuous commentary highlighting the physicality of the black athlete yet emphasizing the intellectual and leadership abilities of the white athlete.

Because sport continues to contribute to racial ideologies, the employment of critical race theory (CRT) has been fruitful in examining sporting experiences, and it has provided critical insight in the intersection of race and sport. CRT was actually a movement that started in the 80 s and has given birth to various theoretical movements (e.g., Latino Critical Theory, Critical Race Feminism, Asian American Critical Race Studies, and American Indian Critical Race Studies). Initially, it was a group of scholar-activists who were interested in examining and transforming the relationship among race, racism, and power (Delgado and Stefancic, 2001).

There are several core principles that provide insight into the interworkings of race and race relations (see, e.g., Bell, 1980, 1989; Crenshaw, Gotanda, Peller, and Thomas, 1995; Delgado, 1995; Delgado and Stefancic, 2001; Ladson-Billings and Tate, 1997; and Yasso, 2005). For example, the notion that race matters and is an enduring reality in the American life; especially in the lives of people of color in general, and Black specifically. It is an ordinary reality and consistently prevalent in the daily experiences of many people of color. The social structuring of race and the psychic conditioning it induces often culminate in lives lost at the hands of perpetrators infected by racism's virus; knowingly and unknowingly. The use of counter-narratives to the dominant narratives about current social conditions is another tenet of CRT. Other tenets of CRT seek to challenge dominant ideologies and promote a commitment to social justice.

Building on the foundation of Hylton's book, 'Race' and Sport: Critical Race Theory (2009), Hawkins, Carter-Francique, and Cooper's (2017) volume on CRT and Black sporting experiences in the United States informs of how race and racism are situated in sporting practices of Black collegiate and professional athletes. Several authors contributed chapters in this volume to expose the intercentricity of race and racism, provide a counter-narrative to the dominant narrative about Black athletes, and provide a revolutionary framework that promotes racial justice.

CRT is useful in providing a counter-narrative to the dominant narrative regarding racial progress Blacks have made in sports. The prominent narrative, 
when examining the representation on the field and in a few coaching positions, is that Blacks have fared well, however, the counter-narrative is that within the sports of intercollegiate football and men's basketball and in the NFL and National Basketball League (NBA), there is a racial imbalance in power and in wealth transfer where whites benefit significantly from the athletic labor of the Black body as owners, administrators, and coaches. Thus, the institutionalization of white supremacy is reinforced in these sporting practices.

Deposing of white supremacy and its social arrangements will take revolutionary measures undergirded by revolutionized theories like CRT, and more specifically interest convergence; where the interests of whites to accumulate capital will converge with Blacks seeking racial justice and a balance in power. Thus, the use of protest has been necessary means throughout the history of this country to make progress towards equity and equality; whether it was voting rights, access to public facilities, and equitable educational resources.

A dominant theme in the sporting practices of Blacks in the United States has been the use of sport as a platform to make a political statement. In a country that has consistently denied Blacks humanity, our very existence has been and continues to be political and politicized. Therefore, as survivors of human degradation and daily microaggressions, just showing up in the arena or running on the field makes a political statement. So, whether it is the Jack Johnson's desire for self-expression, Paul Robeson's fight for political inclusion, Jesse Owens' call for economic inclusion, Althea Gibson's fight for legitimacy, Muhammad Ali's protest for religious expression (like Muhammad Ali), or the raised fists of John Carlos and Tommie Smith in their protest for social and racial justice in the United States, sport has served as a platform for social and racial activism.

This activism continues in our modern era of sport with Venus Williams's call for equity in gender pay for men and women competing in Grand Slam events back in 1998 or the Williams' boycott of Indian Wells because of the racist atmosphere during the 2001 tournament. Furthermore, the racial injustice and police brutality against Blacks produced a tipping point for Colin Kaepernick in 2016, while a player for the San Francisco 49ers. Again, there is a long history of athletes using sporting events as a platform to make a political statement, thus, Mr. Kaepernick simply took up the baton of social activism with his act of kneeling during the playing of national anthem. He has been joined by the women cheerleaders of Howard University and thousands of others at various levels of sport participation who have decided to take a stand by taking a knee.

The significance of protests and the economic impact they engender are debatable. Regarding the "take a knee" protest, Watanabe, Yan, and Soebbing (2017) are examining how the "take a knee" protests are causing market disruption in the NFL. Preliminary data suggests that ticket sales are being impacted, but it is yet to be determined if it is specifically a result of this protest or other market conditions. However, CBS MoneyWatch have reported that operators of two of the largest U.S. ticket marketplaces say they are seeing declines in orders for 
NFL games amid the controversy of the "take a knee" protests (Berr, 2017a). Papa John's pizza corporation has blamed the "take a knee" protest during the playing of the national anthem for taking a multimillion-dollar slice out of its pizza earnings (Dickey, 2017). Berr (2017b) has also reported that the NFL television ratings are impacted with viewership down $11 \%$ during midseason. Additional qualitative and quantitative research is necessary to determine the actual impact this protest has had on the NFL and NFL sponsors. Finally, NBC broadcaster suggest the NFL rating decline may be a result of the comments President \#45 made at a rally in Alabama where he insisted that NFL owners should fire the players who protested during the playing of the national anthem. It is suggested by Nielsen data that the week after Trumps that NFL ratings drop 4\% from the prior week to his comments (Snider, 2017). Furthermore, besides disrupting the profits of these corporations, will policies be implemented and enforced to address the issue of police brutality against Blacks in the United States? Most important to this initial market disruption is whether the interest of whites in accumulating capital will converge with the interests of Black seeking racial justice? How and will NFL owners, in their respective cities, join with city officials and seek to address issues of police brutality, racial profiling, and other racial injustices?

\section{Conclusion}

The prevalence of race and racism in the United States has impacted the sporting experiences of Blacks, specifically, and other people of color, in general. In terms of representation, Blacks continue to be overrepresented in revenue generating intercollegiate sports (Hawkins, 2010) and the sports of professional football and basketball, while an increasing Latin American presence is being witnessed in Major League Baseball. Furthermore, the presence and success of Black women in Olympic swimming (Simone Manuel), boxing (Claressa Chields), Water Polo (Ashleigh Johnson), shot putting (Michelle Carter), and gymnastics (Gabby Douglas and Simone Biles), or in professional tennis with young Black women like Sloane Stevens, Madison Keys, and so on, are continuing the legacy of Althea Gibson, Zina Garrison, the Williams sisters, and other Black women athlete who were vanguards. Based on the representation and the performances of Black women in these sports, the future looks promising for young Black girls in country club sports; sports where they have had limited access, more so due to race and class rather than athletic ability.

Ideologically, however, this racial progress on the field and in the arenas in the United States will further the racist beliefs that are rooted in scientific racism, where the innate physicality of the Black body warrants it superior athletically, but intellectually inferior. Thus, Blacks are more suitable and acceptable in their role as athletes, but lack the intellectual abilities to be leaders, coaches, and administrators. Consequently, the beliefs in the superior physicality and 
intellectual inferiority of the Black body corroborates the reproduction of the imbalance of power and wealth transfer in sport to benefit whites. The meaning of the Black athlete will continue to serve the needs of white supremacy, until emancipatory structures are created to reduce the imbalance in power and wealth transfer.

Critical research that continually exposes this imbalance in power and wealth is necessary, whether it is the disproportionate amount of Black athletes in revenue generating sports at predominantly white institutions and their low graduate rates or the disproportionate amount of Black players in the NBA and NFL but the small percentage of Blacks in leadership positions or owners of these teams. The efforts of critical research scholars in giving a voice to the previously voiceless provide the counter-narratives that are necessary for programmatic development to enhance the sporting experiences of Black athletes. For example, the work Dr. Akilah Carter-Francique is doing with her Sista to Sista program at Prairie View University, where she has developed a holistic development program for Black female collegiate athletes, which is undergirded with the research she conducts on the experiences of Black female collegiate athletes (Sista to Sista, 2018). Another program that is grounded in critical race methodology is the Collective Uplift program at the University of Connecticut directed by Dr. Joseph Cooper (Collective Uplift, 2018). It is also a holistic development support program designed to assist Black male college athletes matriculate through the challenges they experience at predominantly white institutions. These are examples of efforts that are being developed to convert these once oppressive structures in regards to athletic exploitation into emancipatory structures where Black athletes are matriculating to graduation and transitioning to being leaders in their respective careers.

Furthermore, the critical race methodology of counter-storytelling, where counter-narratives are produced will not only inform policies that impact Blacks participation in sports but also help reshape the dominant public perception regarding the Black sporting experiences. These narratives also challenge dominant ideologies about racialized performance and representation and present alternative perspectives regarding the socialization patterns and cultural norms that influence the Black sporting experience opposed to the scientific racist beliefs in the genetic physical superiority of the Black athlete.

In And We Are Not Saved: The Elusive Quest for Racial Justice, Professor Derrick Bell proclaims: "It appears that the worst fears have been realized: we have made progress in everything, yet, nothing has changed" (1989, p. 10). This captures the overall theme for this chapter and it may suggest a hopeless future, in regards to race relations. Recovering from the resurgence and radicalization of white supremacy's ideals will take a concerted effort from those seeking to make sure that the racial inequalities and inequities experienced anywhere are challenged, even in the context of sport, so that they do not threaten the racial justice we have achieved at this point in our human development. 


\section{Notes}

1. President \#45 will be used instead of invoking the name Donald J. Trump.

2. The terms Black and African American are used interchangeably in this chapter.

3. Beyond making public statements regarding their connection to and benefit from slavery, several of these institutions have made public apologized and provide other concessions. For example, in 1838, Georgetown University sold 272 slaves to secure its financial future. Two buildings were renamed to honor theses slaves, and Georgetown granted preferential admission treatment to the descendants of these slaves; similar to admission consideration it offers children of alumni. Other institutions, like Yale University, Harvard University, and University of Virginia, either renamed buildings that were named after advocates of slavery or slave owners, removed monuments associated with their slave history, and/or constructed memorials to recognized enslave people who benefit these institutions.

\section{References}

Bell, D. 1989. And we are not saved: The elusive quest for racial justice. New York: Basic Books.

Berghorn, F. J., Yetman, N. R., and Hanna, W. E. 1988. Racial participation and integration in men's and women's intercollegiate basketball: Continuity and change, 1959-1985. Sociology of Sport Journal, 5(2), 87-106.

Bernhard, L. M. 2014. Nowhere for me to go: Black female student-athlete experiences on a predominantly white campus. Journal for the Study of Sports and Athletes in Education, 8, $67-76$.

Berr, J. 2017a. NFL national anthem protest denting ticker sales. CBS MoneyWatch. Available from www.cbsnews.com/news/nfl-national-anthem-protest-denting-ticket-sales/ [Accessed 1 December 2017].

Berr, J. 2017b. NFL national anthem protest denting ticker sales. CBS MoneyWatch. Available from www.cbsnews.com/news/nfl-national-anthem-protest-denting-ticket-sales/ [Accessed 1 December, 2017].

Bimper Jr., A. Y. and Harrison Jr., L. 2011. Meet me at the crossroads: African American athletic and racial identity. Quest, 63(3), 275-288.

Blalock, H. M. 1962. Occupational discrimination: Some theoretical propositions. Social Problems, 9(3): 240-247.

Blalock, H. M. 1967. Toward a theory of minority group relations. New York: John Wiley and Sons.

Bruening, J., Armstrong, K., and Pastore, D. 2005. Listening to the voices: The experiences of African American female student-athletes. Research Quarterly for Exercise and Sport, 76(1), 82-100.

Carrington, B. 2010. Race, sport and politics: The sporting Black diaspora, Los Angeles, CA: Sage.

Carter, A. F. 2008. Negotiation identities: Examining African American female collegiate athlete experiences in predominantly white institutions. Ph.D. dissertation, University of Georgia.

Carter-Francique, A., and Richardson, F. 2015. Black female athlete experiences at historically black colleges and universities. In B. Hawkins, J. Cooper, A. Carter-Francique, and J. K. Cavil, eds. The athletic experience at historically Black colleges and universities. Lanham, MD: Rowman \& Littlefield, 61-83. 
Collective Uplift. 2018. Available from https://wp.uplift.education.uconn.edu/our-goals/ [Accessed 9 February 2018].

Cooper, J. N., Cooper, J. E. and Baker, A. R. 2016. An anti-deficit perspective of Black female scholar-athlete's achievement experiences at a Division I Historical White Institution (HWI). Journal for the Study of Sports and Athletes in Education, 10(2), 109-131.

Corbett D., and Johnson W. 1993. The African-American female in collegiate sport: Sexism and racism. In D. Brooks and R. Althouse, eds. Racism in college athletics: The African American athlete's experience. Morgantown, WV: Fitness Information Technology, 199-225.

Crenshaw, K., Gotanda, N., Peller, G., and Thomas, K. 1995. Critical race theory: The key writings that formed the movement. New York: New Press.

Davis, L. R. 1990. The articulation of difference: White preoccupation with the question of racially linked genetic differences among athletes. Sociology of Sport Journal, 7(2), 179-187.

Delgado, R. 1995. Critical race theory: The cutting edge. Philadelphia: Temple University Press.

Delgado, R., and Stefancic, J. 2001. Critical race theory: An introduction. New York: New York University Press.

Dickey, J. 2017. Papa John's mess reveals drawbacks of NFL's power. Available from www. si.com/nfl/2017/11/06/papa-johns-john-schnatter-nfl-protests-alexander-ovechkin-putin [Accessed 22 January 2018].

Edwards, H. 2016. Harry Edwards keynote address at North American Society for the Sociology of Sport conference. Available from www.youtube.com/watch?v=OimoyyxOHpE [Accessed 16 January 2018].

Hallinan, C. J. 1991. Aborigines and positional segregation in Australian Rugby League. International Review for the Sociology of Sport, 26(2), 69-79.

Harper, S. R. 2016. Black male student-athletes and racial inequalities in NCAA Division I college sports. Available from https://equity.gse.upenn.edu/sites/default/files/publications/ Harper_Sports_2016.pdf [Accessed 15 January 2018].

Harrison, L., Harrison, C. K., and Moore, L. N. 2002. African American racial identity and sport. Sport, Education, and Society, 7(2), 121-133.

Hawkins, B. J. 2010. The new plantation: Black athletes, college sports, and predominantly White NCAA Division I Institutions. New York: Palgrave Macmillan.

Hawkins, B. J., Carter-Francique, A. R., and Cooper, J. N. 2017. Critical race theory and American sport. New York: Palgrave Macmillan.

Heitner, D. 2016. Colin Kaepernick tops jersey sales in NFL. Forbes. Available from www. forbes.com/sites/darrenheitner/2016/09/07/colin-kaepernick-tops-jersey-sales-in-nfl/ [Accessed 29 January 2018].

Hylton, K. 2009. 'Race' and sport: Critical race theory, New York: Routledge.

Johnson, N. R., and Marple, D. P. 1973. Racial discrimination in professional basketball. Sociological Focus, 6(4), 6-18.

Koch, J. V., and Vander Hill, C. W. 1988. Is this discrimination in the Black man's game? Social Science Quarterly, 69(1), 83-94.

Ladson-Billings, G., and Tate IV, W. F. 1997. Toward a critical race theory of education. Teachers College Record, 97(1), 47-68. 
Lee, C. 2007. Cultural convergence: Interest convergence theory meets the cultural defense. Arizona Law Review, 49, 912-958.

Leonard, D. J. 2014. Dilemmas and contradictions: Black female athletes. In L. L. Martin, ed., Out of bounds: Racism and the Black athlete. Santa Barbara, CA: Praeger, 209-230.

Leonard, W. M. 1987. Stacking in college basketball: A neglected analysis. Sociology of Sport Journal, 4(4), 403-409.

Loy, J. W., and McElvogue, J. F. 1970. Racial segregation in American sport. International Review of Sport Sociology, 5(1), 5-24.

Maguire, J. A. 1988. Race and position assignment in English soccer: A preliminary analysis of ethnicity and sport in Britain. Sociology of Sport Journal, 5(3), 257-269.

Marable, M. 1998. Speaking truth to power: Essays on race, resistance, and radicalism. Boulder, CO: Westview Press.

McDowell, J., and Carter-Francique, A. 2016. Experiences of female athletes of color. In E. Staurowsky, ed., Women and sport: Continuing a journey of liberation to celebration. Champaign, IL: Human Kinetics, 95-115.

McPherson, B. D. 1976. Minority group involvement in sport: The Black athlete. In A. Yiannakis, T. D. McIntyre, M. J. Melnick, and D. P. Hart, eds. Sport sociology. Dubuque, IA: Kendall/Hunt, 153-166.

Melnick, M. J. 1988. Racial segregation by playing in the English football league: Some preliminary observations. Journal of Sport and Social Issues, 12(1), 122-130.

Sista to Sista. 2018. Available from http://sistatosista.org/Sista_to_Sista/Welcome_to_ Sista_to_Sista.html [Accessed 9 February 2018].

Sloan-Green, T., Oglesby, C., Alexander, A., and Franke, N. 1981. Black women in sport. Reston, VA: American Alliance of Health and Physical Education Recreation and Dance Publications.

Smith, Y. 1992. Women of color in society and sport. Quest, 44(2), 228-250.

Smith, Y. 2000. Sociohistorical influences of African American elite sportswomen. In D. Brooks and R. Althouse, eds. Racism in college athletics: The African American Athlete Experience, 2nd ed. Morgantown, WV: Fitness Information Technology, 173-197.

Snider, M. 2017. Are NFL player protests 'massively, massively' hurting TV ratings? USA Today. Available from www.usatoday.com/story/money/business/2017/09/26/ nfl-player-protests-hurting-ratings/703619001/ [Accessed 7 February 2018].

Steinfeldt, J. A., Reed, C., and Steinfeldt, M. C. 2009. Racial and athletic identity of African American football players at historically Black colleges and universities and predominantly White institutions. Journal of Black Psychology, 36(1) 3-24.

TIDE, 2018. The institute for diversity and ethics in sport. Available from www.tidesport.org/ reports.html [Accessed 15 January 2018].

Valentine, J. 2012. New racism and old stereotypes in the National Hockey League: The "stacking" of Aboriginal players into the role of enforcer. In J. Joseph, S. Darnell, and Y. Nakamura, eds. Race and sport in Canada: Intersecting inequalities. Toronto: Canadian Scholars' Press, 107-138.

Watanabe, N., Yan, G., and Soebbing, B. 2017. The political economy of Kaepernick's protests: An alternative understanding of athlete activism. North American Society for the Sociology of Sport paper presentation.

Yasso, T. J. 2005. Who's culture has capital? A critical race theory discussion of community culture wealth. Race ethnicity and education, 8(1), 69-91. 